UDC 338.43:005.591.6

JEL Classification: B 40, M31, Q13 DOI: http://doi.org/10.31617/visnik.knute.2021(137)09

KULIK Anna,

$\mathrm{PhD}$ (Economics), Associate Professor of the Department of Trade of Enterprise and Logistics

Kyiv National University of Trade and Economics

19, Kioto str., Kyiv, 02156, Ukraine

E-mail:a.kulik@knute.edu.ua

ORCID: 0000-0002-2601-3833

\title{
AGRICULTURAL ENTERPRISE INNOVATIVE DEVELOPMENT
}

The article summarizes the state and prospects of innovative development of agricultural entrepreneurship. The influence of new economic realities caused by systemic reforms in the economy on the innovative development of agrarian entrepreneurship in Ukraine for the formation of promising areas of its development is studied. It is established that the current state of the agricultural sector is due to the global impact of technological modernization, which is not always appropriate and does not meet the real needs and capabilities of agricultural producers. The necessity of developing a strategy of innovative development of the industry and on the basis of historical experience and the latest achievements of the stages of its implementation is proved.

Keywords: agrarian sector, innovative development, entrepreneurship, systemic reforms, strategy, forms of management.

Background. Generalization of the state and formation prospects of the innovative development of agricultural entrepreneurship is an important task. Its relevance is determined by the fact that domestic practice should take into account the features and capabilities of the agricultural sector, its state and mentality, adhere to the basic principles of innovative development in agriculture.

Analysis of recent research and publications has shown that the issues of innovative development of agricultural entrepreneurship need further study and discussion in the scientific world.

The aim of the article is to study the impact of new economic realities, systemic reforms in the economy on the innovative development of agricultural entrepreneurship in Ukraine, formation of promising areas of its development.

Materials and methods. Methods of economic theory, comparisons, statistical analysis and formalization were used in the paper. The period from 2010 to 2019 was used for the stydy.

Results.The current state of the agricultural sector leads to the global impact of technological modernization, which is not always appropriate and does not meet the real needs and capabilities of agricultural producers.

Systematization of scientific sources and approaches to solving the problems of innovative development of agricultural entrepreneurship has shown a significant impact of new economic realities due to systemic reforms

(C) Kulik A., 2021

ISSN 1727-9313. ВICHИК КНТЕУ. 2021. № 
in the economy and agriculture on the innovative development of agricultural entrepreneurship in Ukraine. According to statistics, we found out how agricultural entrepreneurs reacted to the reforms.

According to the Commercial Code of Ukraine, entrepreneurship is direct independent, systematic activity, exercised at one's own risk, directed at the production of goods, the performance of works or providing services to make profit. Research of the state of agrarian entrepreneurship, according to the statistical data, lays the foundation for understanding how it reacts to the changes in the environment. Table 1 indicates the structure of agribusiness by the enterprise size in the total number of economic entities in 2010-2019.

Table 1

Agricultural production in Ukraine by size of enterprises in 2010-2019

\begin{tabular}{|c|c|c|c|c|c|c|}
\hline \multirow[b]{2}{*}{ Indicator } & \multirow[b]{2}{*}{ Years } & \multirow{2}{*}{$\begin{array}{c}\text { Number } \\
\text { of economic entities, } \\
\text { total, units }\end{array}$} & \multicolumn{4}{|c|}{ Share in the total number of business entities, $\%$} \\
\hline & & & Big & Medium & Small & Micro \\
\hline \multirow{10}{*}{$\begin{array}{c}\text { Total } \\
\text { on economy }\end{array}$} & 2010 & 2183928 & 0.0 & 1.0 & 99.0 & 95.9 \\
\hline & 2011 & 1701620 & 0.1 & 1.2 & 98.7 & 94.5 \\
\hline & 2012 & 1600127 & 0.0 & 1.3 & 98.7 & 94.4 \\
\hline & 2013 & 1722070 & 0.0 & 1.1 & 98.9 & 95.1 \\
\hline & 2014 & 1932161 & 0.0 & 0.9 & 99.1 & 96.3 \\
\hline & 2015 & 1974318 & 0.0 & 0.8 & 99.2 & 96.8 \\
\hline & 2016 & 1865530 & 0.0 & 0.8 & 99.2 & 96.5 \\
\hline & 2017 & 1805144 & 0.0 & 0.9 & 99.1 & 96.2 \\
\hline & 2018 & 1839174 & 0.0 & 0.9 & 99.1 & 95.9 \\
\hline & 2019 & 1941625 & 0.0 & 0.9 & 99.1 & 96.0 \\
\hline \multirow{10}{*}{$\begin{array}{c}\text { Agriculture, } \\
\text { forestry and } \\
\text { fisheries }\end{array}$} & 2010 & 80321 & 0.0 & 4.3 & 95.7 & 90.2 \\
\hline & 2011 & 61488 & 0.0 & 5.3 & 94.7 & 85.6 \\
\hline & 2012 & 68497 & 0.0 & 4.6 & 95.4 & 87.1 \\
\hline & 2013 & 71058 & 0.0 & 4.1 & 95.9 & 87.8 \\
\hline & 2014 & 75660 & 0.0 & 3.8 & 96.2 & 87.6 \\
\hline & 2015 & 79284 & 0.0 & 3.2 & 96.8 & 90.4 \\
\hline & 2016 & 74620 & 0.0 & 3.4 & 96.6 & 89.7 \\
\hline & 2017 & 76593 & 0.0 & 3.2 & 96.9 & 89.9 \\
\hline & 2018 & 76328 & 0.0 & 3.0 & 97.0 & 89.7 \\
\hline & 2019 & 75450 & 0.1 & 3.0 & 96.9 & 89.7 \\
\hline
\end{tabular}

Sources: Data of the State Statistics Service of Ukraine [16].

Quantity and structure of agrarian entrepreneurship are relatively stable, e.i. the total quantity of legal entities decreased by $15.79 \%$ in 2019 , in contrast to 2010 , and only by $6.06 \%$. in the agricultural sector. In the macroeconomic dimension, the aforementioned fluctuation is considered to be negligible; therefore, it is possible to argue its constancy (stability). Small businesses account for the major share - above $99 \%$, for example $96 \%$ are microbusinesses. Large enterprises are represented by a low number (34 in 2019), therefore, they are not shown in the structure.

The dynamics of subjects of agrarian entrepreneurial activity by the form of ownership is depicted in table 2. 
Table 2

Dynamics of the number of agricultural enterprises by forms of economic entities in 2010-2017

\begin{tabular}{|l|c|c|c|c|c|c|c|c|}
\hline $\begin{array}{c}\text { Forms } \\
\text { of business entities }\end{array}$ & 2010 & 2011 & 2012 & 2013 & 2014 & 2015 & 2016 & $2017 *$ \\
\hline Farms & 41726 & 41488 & 34035 & 34168 & 33084 & 32303 & 32127 & 32199 \\
\hline$\%$ to total & 73.86 & 73.91 & 68.88 & 69.67 & 71.61 & 71.18 & 70.82 & 71.12 \\
\hline Business associations & 7769 & 7757 & 8235 & 8245 & 7750 & 7721 & 7718 & 7705 \\
\hline$\%$ to total & 13.75 & 13.82 & 16.66 & 16.81 & 16.78 & 17.01 & 17.01 & 17.02 \\
\hline Private enterprises & 4243 & 4140 & 4220 & 4095 & 3772 & 3627 & 3603 & 3599 \\
\hline$\%$ to total & 7.51 & 7.38 & 8.54 & 8.35 & 8.16 & 7.99 & 7.94 & 7.95 \\
\hline State-owned & 322 & 311 & 296 & 269 & 228 & 241 & 237 & 225 \\
\hline$\%$ to total & 0.57 & 0.55 & 0.60 & 0.55 & 0.49 & 0.53 & 0.52 & 0.50 \\
\hline
\end{tabular}

*Excluding the temporarily occupied territories

Sources: Data of the State Statistics Service of Ukraine [16].

Considering the abovementioned data, it is claimed that the quantity of farms has declined by $22.8 \%$ over the analyzed period, the number of business associations remains constant, private enterprises has decreased by $15.2 \%$, state-owned has decreased by $30 \%$. Data regarding the following years have not been compiled by the State Statistics Service of Ukraine. Nevertheless, the mentioned indicators confirm general tendency, concerning the predominance of small businesses in the general structure. We should note that cooperative has become one of the directions of the development in agriculture lately. According to the data provided by the Ministry of Agrarian Policy and Food of Ukraine, a number of agricultural cooperatives has grown by 125 units to 735 over 2018. Despite the absence of constancy in statistics, the state relies on this type of entrepreneurial activity.

The effectiveness of agrarian entrepreneurship is substantiated by the volume of production (goods, services), illustrated by the data in table 3 over the period from 2012 to 2019.

Table 3

Production volume of enterprises (goods, services) in 2012-2019

\begin{tabular}{|c|c|c|c|c|c|c|c|}
\hline \multirow{2}{*}{ Indicator } & \multirow{2}{*}{ Year } & \multicolumn{2}{|c|}{ Big } & \multicolumn{2}{c|}{ Medium } & \multicolumn{2}{c|}{ Small } \\
\cline { 3 - 8 } & & UAH, mln & $\%$ & UAH, mln & in \% & UAH, mln & $\%$ \\
\hline \multirow{5}{*}{ Total } & 2012 & 1274246.3 & 49.1 & 971932.5 & 37.5 & 347167.9 & 13.4 \\
\cline { 2 - 8 } & 2013 & 1136699.8 & 46.0 & 934833.2 & 37.9 & 397257.2 & 16.1 \\
\cline { 2 - 8 } & 2014 & 1222747.8 & 44.9 & 1041001.4 & 38.2 & 460222.0 & 16.9 \\
\cline { 2 - 8 } & 2015 & 1439883.0 & 44.8 & 1258421.6 & 39.1 & 516983.3 & 16.1 \\
\cline { 2 - 8 } & 2016 & 1581304.9 & 40.7 & 1613257.8 & 41.5 & 690054.9 & 17.8 \\
\cline { 2 - 8 } & 2017 & 2039421.3 & 41.8 & 1957363.4 & 40.2 & 875963.4 & 18.0 \\
\cline { 2 - 8 } & 2018 & 2352713.6 & 37.9 & 2247182.9 & 36.2 & 1607791.0 & 25.9 \\
\cline { 2 - 8 } & 2019 & 2503075.2 & 35.9 & 2507605.1 & 35.9 & 1971187.1 & 28.2 \\
\hline \multirow{5}{*}{$\begin{array}{c}\text { Agriculture } \\
\text { forestry and } \\
\text { fishery }\end{array}$} & 2012 & 23373.6 & 13.3 & 111771.7 & 63.6 & 40596.3 & 23.1 \\
\cline { 2 - 8 } & 2013 & 24723.5 & 12.9 & 106560.2 & 55.6 & 60371.4 & 31.5 \\
\cline { 2 - 8 } & 2014 & 41015.3 & 14.6 & 144677.3 & 51.5 & 95234.1 & 33.9 \\
\cline { 2 - 8 } & 2016 & 58731.0 & 16.8 & 213147.9 & 52.1 & 127234.2 & 31.1 \\
\cline { 2 - 8 } & 2017 & 46423.6 & 9.1 & 245904.5 & 52.8 & 161821.0 & 34.8 \\
\cline { 2 - 8 } & 2018 & 63457.6 & 10.3 & 312359.7 & 50.7 & 240276.0 & 39 \\
\cline { 2 - 7 } & 2019 & 80991.8 & 12.7 & 312694.1 & 49.1 & 242975.5 & 38.2 \\
\hline
\end{tabular}

Sources: Data of the State Statistics Service of Ukraine [16]. 
It is clear that agriculture is about $9.1 \%$ of the volume of production in the increasing dynamics, after recession in 2017. Moreover, the largest share - up to $50 \%$ - is held by medium enterprises during specific periods, followed by small, which are about $38.2 \%$, and finally large, maximum of $12.7 \%$ of production.

Profitability of business entities by their size and type of economic activity in 2010-2019 is shown in table 4.

Table 4

Production profitability of agricultural enterprises by their size and type of economic activity in 2010-2019

\begin{tabular}{|c|c|c|c|c|c|c|c|}
\hline \multirow[t]{2}{*}{ Indicator } & \multirow[b]{2}{*}{ Year } & \multicolumn{3}{|c|}{$\begin{array}{l}\text { The level of profitability } \\
\text { of operating activities }\end{array}$} & \multicolumn{3}{|c|}{$\begin{array}{c}\text { The level of profitability } \\
\text { of all activities }\end{array}$} \\
\hline & & big & medium & small & big & medium & small \\
\hline \multirow{10}{*}{ Total } & 2010 & 3.9 & 5.0 & 1.8 & 0.2 & 2.3 & -5.7 \\
\hline & 2011 & 6.2 & 6.0 & 4.2 & 3.3 & 1.2 & -2.5 \\
\hline & 2012 & 5.2 & 5.0 & 4.1 & 0.9 & 2.2 & -3.3 \\
\hline & 2013 & 5.0 & 3.2 & 2.2 & 0.6 & -0.1 & -6.2 \\
\hline & 2014 & 0.7 & -3.6 & -17.9 & -11.1 & -12.5 & -26.5 \\
\hline & 2015 & 4.0 & 0.0 & -4.2 & -7.0 & -5.0 & -13.6 \\
\hline & 2016 & 8.8 & 6.9 & 5.2 & 2.4 & 0.7 & -3.6 \\
\hline & 2017 & 11.2 & 7.3 & 6.5 & 5.2 & 3.1 & -2.0 \\
\hline & 2018 & 9.1 & 7.0 & 8.3 & 5.2 & 4.6 & 2.7 \\
\hline & 2019 & 10.2 & 10.0 & 10.7 & 6.8 & 8.6 & 7.0 \\
\hline \multirow{10}{*}{$\begin{array}{l}\text { Agriculture, } \\
\text { forestry } \\
\text { and fishery }\end{array}$} & 2010 & 29.8 & 23.2 & 17.9 & 22.0 & 16.8 & 11.2 \\
\hline & 2011 & 30.6 & 21.0 & 25.9 & 25.2 & 15.5 & 21.8 \\
\hline & 2012 & 29.7 & 19.6 & 22.7 & 24.6 & 13.1 & 16.7 \\
\hline & 2013 & 20.0 & 8.4 & 12.9 & 15.3 & 6.3 & 8.1 \\
\hline & 2014 & 23.8 & 20.8 & 18.5 & 14.9 & 6.9 & 9.8 \\
\hline & 2015 & 54.3 & 37.8 & 41.4 & 45.4 & 23.4 & 32.4 \\
\hline & 2016 & 29.3 & 30.4 & 37.2 & 24.7 & 21.6 & 30.0 \\
\hline & 2017 & 24.6 & 20.8 & 24.1 & 20.5 & 15.4 & 15.6 \\
\hline & 2018 & 22.9 & 17.1 & 18.6 & 21.2 & 14.3 & 10.9 \\
\hline & 2019 & 8.3 & 23.2 & 13.4 & 6.1 & 23.6 & 9.6 \\
\hline
\end{tabular}

Sources: Data of the State Statistics Service of Ukraine [16].

According to the data, it is clear that agrarian enterprises of all types demonstrate high profitability, whereas the overall economy is characterized by financial losses over the analyzed period. By the level of profitability, medium enterprises are the most stable, although such trend differs with years. Factual significance of the added value (according to the production expenses) of agrarian enterprises in 2012-2019 is shown in table 5.

Calculations according to this factor indicate that the largest contribution to the formation of added value is made by medium enterprises (about 56.2\%). Significant share for small agricultural enterprises is 39.0\%. The market share of large enterprises fell from $14 \%$ in 2010 to $4.8 \%$ in 2019 .

Concerning the investments, according to the data provided by the Ministry of Agrarian Policy and Food of Ukraine [17], 474 investment projects were realized in the agrarian sector in 2018. In specific, $18.6 \%$ of them are those related to processing, storage of cereals and industrial crops, 
$12.2 \%$ - fruit and vegetable storage, $4.2 \%$ - perennial plantings, $3 \%$ - irrigation, $23.6 \%$ - animal husbandry, $12.4 \%$ - swine breeding. Agro-industrial sector of Ukraine implemented 380 investment projects worth UAH 27.9 bln as of January 1, 2017. The primary source of financing capital investments is equity funds, their share is $74.3 \%$. The cost of investment projects varies from UAH $0.1 \mathrm{mln}$ to UAH $9.6 \mathrm{bln}$.

Table 5

The added value according to the production expenses of enterprises in 2012-2019

\begin{tabular}{|c|c|c|c|c|c|c|c|}
\hline \multirow{2}{*}{ Indicator } & \multirow{2}{*}{ Year } & \multicolumn{2}{|c|}{ Big } & \multicolumn{2}{c|}{ Medium } & \multicolumn{2}{c|}{ Small } \\
\cline { 3 - 8 } & & mln, UAH & $\%$ & mln, UAH & in \% & mln, UAH & $\%$ \\
\hline \multirow{5}{*}{ Total } & 2012 & 482248.5 & 47.5 & 424927.2 & 41.8 & 108327.8 & 10.7 \\
\cline { 2 - 8 } & 2013 & 416121.0 & 42.6 & 410647.5 & 42.0 & 150376.5 & 15.4 \\
\cline { 2 - 8 } & 2014 & 530792.4 & 43.0 & 486547.5 & 39.4 & 216750.2 & 17.6 \\
\cline { 2 - 8 } & 2015 & 585131.8 & 44.0 & 537956.0 & 40.5 & 206176.7 & 15.5 \\
\cline { 2 - 8 } & 2016 & 680193.2 & 39.9 & 738338.3 & 43.4 & 284139.0 & 16.7 \\
\cline { 2 - 8 } & 2017 & 844774.1 & 40.2 & 865520.8 & 41.2 & 389209.9 & 18.6 \\
\cline { 2 - 8 } & 2018 & 895101.1 & 38.7 & 956970.8 & 41.4 & 458508.7 & 19.9 \\
\cline { 2 - 8 } & 2019 & 999622.4 & 36.4 & 1175647.0 & 42.9 & 569026.4 & 20.7 \\
\hline \multirow{5}{*}{$\begin{array}{c}\text { Agriculture, } \\
\text { forestry and } \\
\text { fishery }\end{array}$} & 2012 & 10491.4 & 14.1 & 43007.4 & 57.8 & 20908.4 & 28.1 \\
\cline { 2 - 8 } & 2013 & 9893.1 & 14.2 & 34207.9 & 49.1 & 25568.9 & 36.7 \\
\cline { 2 - 8 } & 2014 & 15683.0 & 12.5 & 59846.4 & 47.7 & 49934.7 & 39.8 \\
\cline { 2 - 8 } & 2015 & 32361.9 & 17.6 & 94143.7 & 51.2 & 57368.8 & 31.2 \\
\cline { 2 - 8 } & 2016 & 19814.9 & 10.6 & 96644.4 & 51.7 & 70473.8 & 37.7 \\
\cline { 2 - 8 } & 2018 & 59180.8 & 4.5 & 91920.6 & 47.0 & 94746.4 & 48.5 \\
\cline { 2 - 8 } & 2019 & 9900.0 & 4.8 & 105103.4 & 52.1 & 90921.5 & 45.1 \\
\hline
\end{tabular}

Sources: Data of the State Statistics Service of Ukraine [16]

The majority of investment activity, according to the identical source, is in the following regions: Vinnytsa (UAH $6.3 \mathrm{bln}$ ), Kyiv (UAH $1.1 \mathrm{bln}$ ), Poltava (UAH 0.6 bln), Cherkasy (UAH 0.4 bln) and Sumy (UAH 0.4 bln). Manyprojects are implemented in Poltava (69), Lviv (64), Vinnytsa (48), Chernivtsi (43) and Cherkasy (41) regions. According to the forecasts, the realization of those projects in 2018 create approximately 16 thousand workplaces. Furthermore, general growth in investment attraction of the agriculture, improvement of the business climate in Ukraine, stimulating investment attraction, including foreign, restoration of state support programs for the development of small and medium business are supposed to encourage the growth of the number of agricultural entrepreneurs. Simultaneously, it is forecasted that new jobs will be created and the unemployment rate will decrease, rural territories will be re-populated, etc.

Such state of the agricultural development dictates the necessity of its structural re-orientation, one example of which is innovation and technology transfer.

According to the data presented by Scientific Analytical report, Innovation activity in Ukraine in 2019 [18], conducted analysis of five international rankings, which evaluates innovativeness of various countries' economies, states that the effectiveness of innovation activity in Ukraine in 
2019-2020 decreased by all indices. The expenditure reduction on research and development and education as a percentage of GDP, which has affected the indicators of the quality of human capital and research are among the abovementioned reasons. The level of development of innovation infrastructure remains at a quite low level in comparison to the world's leading countries. Weaknesses include the protection of intellectual property rights, the development of clusters, and proportion of the population who are the Internet users. Among the accomplishements of Ukraine are improvement of the position on the following indicators: the index of attracting talent, market and regulatory opportunities in the labor market, institutions, creativity, penetration of high technology, skills.

In comparison to 2018, the amount of financing for innovation activity has increased up to UAH $14220.9 \mathrm{mln}$, simultaneously, the percentage of financing of innovation activity has remained at $0.3 \%$. In 2019, personal funds of enterprises, UAH $12474.9 \mathrm{mln}$ (or $87.7 \%$ of the total amount of financing for innovations), remained the principal source of financing for innovation activity. State budget funds have been received by 6 enterprises, totaling at UAH $556.5 \mathrm{mln}$ (3.9\%); foreign investors' funds have been received by 3 enterprises in the amount of UAH $42.5 \mathrm{mln}(0.3 \%)$; amount from other sources has totaled at UAH $1147.0 \mathrm{mln}(8.1 \%)$.

The largest shares of innovatively active enterprises for the production of food products are $16.8 \%$, production of machinery and equipment is $10.2 \%$, depending on the types of economic activity.

According to the conclusions drawn by the Analytical Reference "Implementation of priority areas of science and technology and obtained results in 2019", the results are in (table 6).

Table 6

Financing for $R \& D$ by priority areas in terms of budget funding

\begin{tabular}{|l|c|c|c|c|}
\hline & \multirow{2}{*}{$\begin{array}{c}\text { The amount } \\
\text { Areas of budget funding }\end{array}$} & \multicolumn{3}{|c|}{ Including by priority areas } \\
\cline { 4 - 5 } & $\begin{array}{c}\text { for R\&D, } \\
\text { in total, } \\
\text { UAH mln }\end{array}$ & $\begin{array}{c}\text { The } \\
\text { funding, } \\
\text { UAH mln }\end{array}$ & $\begin{array}{c}\text { \% of the amount } \\
\text { of R\&D funding } \\
\text { in priority areas }\end{array}$ & $\begin{array}{c}\text { \% of the amount } \\
\text { of funding } \\
\text { of the areas }\end{array}$ \\
\hline $\begin{array}{l}\text { Fundamental scientific } \\
\text { research (FSR) }\end{array}$ & 3366.80 & 3366.80 & 66.90 & 100.00 \\
\hline $\begin{array}{l}\text { Applied Research and } \\
\text { Development (R\&D) }\end{array}$ & 1972.65 & 1592.31 & 31.65 & 80.72 \\
\hline $\begin{array}{l}\text { State targeted scientific and } \\
\text { science technology } \\
\text { programs (STSTP) }\end{array}$ & 19.30 & 16.80 & 0.33 & 87.05 \\
\hline $\begin{array}{l}\text { Developments by public } \\
\text { procurement }\end{array}$ & 42.88 & 42.88 & 0.85 & 100.00 \\
\hline $\begin{array}{l}\text { Projects within the } \\
\text { framework of international } \\
\text { science and technology } \\
\text { cooperation }\end{array}$ & 13.57 & 13.57 & 0.27 & 100.00 \\
\hline Total funding for R\&D & 5415.20 & 5032.36 & 100.00 & 92.93 \\
\hline
\end{tabular}

Sources: [19]. 
The largest amounts of total fund expenditures by priority areas in 2019, similarly to the previous years, were directed by the following principal institutions, such as the NAS, the MES, and the NAMS, which most anticipated expenditures for research in general. Thus, in the reporting year, the NAS has allocated UAH $3308.13 \mathrm{mln}$, which accounts for $100 \%$ of the amount of expenditures anticipated by the NAS in general, for the implementation of priority areas, as well as $65.7 \%$ of total expenditures on research by priority areas. The MES has allocated UAH $686.19 \mathrm{mln}$, which accounts for $89.2 \%$ and $13,6 \%$ respectively, the NAMS has allocated UAH $365.70 \mathrm{mln}$, which accounts for $100 \%$ and $7.3 \%$ respectively. The NAAS has invested UAH $362.68 \mathrm{mln}$, which accounts for $100 \%$ and $7.4 \%$ respectively. The analysis of the general fund expenditures for R\&D by priority areas shows that the trend of distribution of funds remains the same as in previous periods (2015-2018).

The implementation of priority areas in 2019 was carried out, as in the previous years, mainly through basic funding for research and development, which accounted for $98.5 \%$ of total expenditures in priority areas. The Funds were directed for the purposes in such areas of budget funding as: "Fundamental scientific research" (66.9\%) and "Applied research and development" (31.6\%).

In 2019, 6420 STRs were performed in priority areas $(89.5 \%$ of the total number performed in the reporting year at the expense of the general fund of the state budget), 11780 STP units were created (84.1\% of the total number created), $66.0 \%$ were implemented (7776 units). The largest number of STPs -7533 units (63.9\% of the total number created by priority areas) were created by the priority area "Fundamental scientific research", portion of which, 4848 units (64.3\%), was implemented.

In $2019, R \& D$ was conducted by 45 out of 46 priority thematic areas, which were approved by the resolution of the Cabinet of Ministers of Ukraine dated 07.09.2011 № 942 (as amended). In a similar manner to the previous years, in the reporting year, immensely low financing of certain priority thematic areas was recorded.

An important aspect in the revision of priority areas according to the Decree of the President of Ukraine "On Sustainable Development Goals of Ukraine until 2030" from 30.09.2019 № 722 is consideration of national tasks and indicators of progress in the achievement of Sustainable development goals, which are included in the National report "Sustainable development goals: Ukraine".

Individual data of budget expenditure on the funding of priority areas of innovation and technology transfer activity in Ukraine is compiled in table 7.

According to the report [20], in relation to the GDP, funding in 2019 amounted to $0.0082 \%$ (in $2018-0.0082 \%$, in $2017-0.0087 \%$, in $2016-$ $0.0082 \%$ ), e.i, in 2019, actual funding of strategic priorities of innovation activity was at the level of 2016, despite the growth in absolute amounts of funding. 
Budget expenditure on the funding of priority areas of innovation and technology transfer activities in Ukraine in 2016-2019, mIn UAH

\begin{tabular}{|l|c|c|c|c|c|c|c|c|}
\hline \multirow{2}{*}{$\begin{array}{c}\text { Budget } \\
\text { managers }\end{array}$} & \multicolumn{4}{|c|}{$\begin{array}{c}\text { Funding for innovation } \\
\text { and technology transfer activities, total }\end{array}$} & \multicolumn{3}{c|}{ Share of manager in total funding, \% } \\
\cline { 2 - 9 } & 2016 & 2017 & 2018 & 2019 & 2016 & 2017 & 2018 & 2019 \\
\hline NAAS & 112.7 & 148.5 & 133.1 & 250.9 & 58.0 & 57.3 & 51.1 & 53.0 \\
\hline Total & 194.5 & 259.1 & 291.4 & 383.9 & 100.0 & 100.0 & 100.0 & 100.0 \\
\hline
\end{tabular}

Sources: According to the Department of Innovation and Technology Transfer [12].

Thus, the NAS has allocated UAH $3308.13 \mathrm{mln}$, which accounts for $100 \%$ of the amount of expenditures anticipated by the NAS in general in the reporting year, for the implementation of priority areas, as well as $65.7 \%$ of total expenditures on research by priority areas, the MES has allocated UAH $686.19 \mathrm{mln}$, which accounts for $89.2 \%$ and $13.6 \%$ respectively, the NAMS has allocated UAH $365.70 \mathrm{mln}$, which accounts for $100 \%$ and $7.3 \%$ respectively, the NAAS has allocated UAH $362.68 \mathrm{mln}$, which accounts for $100 \%$ and $7.4 \%$ respectively.

In 2019, the amount of two out of four main institutions accounted for $94.0 \%$ summarily and were distributed among the NAS $(65.7 \%)$ and the MES of Ukraine (13.6\%). Expenditures on innovation activity were directed by its six types (in 2017 - by three, in 2018 - by five), of which the largest portion is type of innovation activity "Other", which includes mainly performance of RTD in order of enterprises/organizations.

According to the data provided by the State Statistics Service of Ukraine [16], in recent years, the principal factors that impede innovation activity development of domestic enterprises are as follows: lack of equity ( $80.1 \%$ of researched enterprises), substantial expenditure on innovation $(55.5 \%)$, insufficient state support (53.7\%), high economic risk (41\%), imperfection of the legal framework ( $40.4 \%$ ), extended period of recoupment of innovation $(38.7 \%)$, absence of funds from buyers $(33.3 \%)$, lack of qualified personnel $(20 \%)$, lack of opportunities for cooperation with other enterprises and scientific organizations (19.7\%), lack of data on sales market (17.4\%), lack of information on new technologies (16.1\%).

According to the information of the State Statistics Service, innovation scientific research and developments in Ukraine were conducted by 950 organizations, consisting of $48.1 \%$ related to the state-owned economic sector, $37.0 \%$ - entrepreneurial sector, $14.9 \%$ - higher education over 2018. Nearly half of the expenditure dedicated to the fundamental scientific research accounted for the branch of natural science, $24.8 \%$ for engineering, $8.7 \%$ for agriculture.

At the beginning of 2019, group of companies "ProAgro Group" held a conference "Agrarian Innovation 2018" [20], which gathered experts of agro-company innovation implementation, developers of innovative decisions for agro-sector, as well as representatives of an agrarian field that are 
interested in the innovation technology implementation. Innovation technology of management and control in the modern enterprise were presented, including technologies on effective crop cultivation and information systems for the agroindustrial sector.

Regarding the foreign experience, it is stated that over the last century TOP-10 agrarian innovations [21] are considered to be as follows: formation of cooperatives, hybridization, gasoline-powered tractors, farm credits, soil security, in vitro fertilization in the livestock industry, electrification of rural regions, agrarian chemicals, biotechnology, computers.

Overall, the achievements of agrarian business are rather significant, however, such primary factors as substantial land-bank, cheap labor, tax remissions, state support in production and export of particular commodity of the field. In the meantime, global agriculture is aiming at innovative development.

Ukrainian agrarian business furthermore integrates advanced scientific and technical developments, particularly in the large enterprises, such as "Agroholding Mriya", "Kernel Group", PLC "Ukrlandfarming", "AstartaKyiv" and others, while AgTech area (agrarian technology) is developing actively in the recent years; special funds aimed at attracting investments for ambitious projects have been established [13]. According to the data provided by Bakertilly agency, at least one enterprise exists, covering 5 thous ha, where the fields are cultivated automatically, fertilizers and plant protection products are applied, allowing the involvement of 12 staff members during the high season, savings of sowing material, fertilizers, protection products.

As stated by Agronews, although global agroprocesses are becoming more automated, our farmers often use outdated business practices. However, at least 10 domestic innovative ideas exist that can qualitatively change Ukrainian agriculture [19].

Nevertheless, measures taken by the state insignificantly and extremely slowly influence entrepreneurship and, occasionally have the opposite effect, stimulate the development of rural entrepreneurship. The reason is a set of factors highlighted by the experts: lack of structural social and economic reforms, substantial fluctuations in the national currency rate, financial instability and deterioration of the investment climate in a country, unemployment rate growth, and decrease of population purchasing power.

The complicated financial situation of small and medium enterprises, low investment and innovation activity of small business, disproportion in the structure of business development by the type of economic activity, reduction in lending, lack of current assets create favorable conditions for proceeding deterioration of agrarian entrepreneurship development.

According to the ISD research [22], systemic reforms decrease administrative pressure on business and encourage competition. In particular, governmental price regulation was revoked, specifically for food that is considered to be socially important. In 2017, the law aimed at the protection 
of business from unlawful and unreasonable searches by law enforcement agencies was enforced. Moreover, during this time mandatory document stamping requirement for legal entities was overruled, facilitating business practices. Nevertheless, the desired results of reforms are not achieved yet, previously occupied positions are lost.

Thus, according to the data provided by British analytical center The Legatum Institute [19], Ukraine has taken 112th position, falls in 5 ranks in comparison to 2016, in the global ranking of prosperity which is compiled based on surveys, conducted according to the eight categories: economic quality, social capital, governance, enterprise conditions, health, and personal freedom.

According to the report "Global index of innovations 2019", Ukraine lost 4 positions in the ranking and ranked $47^{\text {th }}$ (in $2018-43^{\text {rd }}$, in $2017-$ $50^{\text {th }}$ ). Ukraine is ranked $2^{\text {nd }}$, following Vietnam, in the ranking of countries with below-average income.

Author Contributions. The directions and purpose of the innovative development of agrarian businesses have been established by generalization of the various sources (table 8).

Table 8

Priority areas and purpose of innovative development of agrarian entrepreneurship in Ukraine

\begin{tabular}{|c|c|}
\hline Areas & Purpose \\
\hline Agro-technology & $\begin{array}{l}\text { Implementation of the most promising agro-technologies to elevate } \\
\text { production productivity; reducing unit costs and enhancing its } \\
\text { competitiveness in domestic and global markets }\end{array}$ \\
\hline $\begin{array}{l}\text { Informational } \\
\text { support }\end{array}$ & $\begin{array}{l}\text { Provision of informational support for innovation activities includes } \\
\text { the following: } \\
\text { establishment and replenishment of data banks of scientific and technical } \\
\text { results and potential opportunities of executors of scientific and technical } \\
\text { programs and projects in priority areas; } \\
\text { communication with remote information centers and databases, including } \\
\text { foreign ones, using Ukrainian and foreign telecommunication systems; } \\
\text { ensuring access for interested organizations and individuals to information } \\
\text { databases (IDB) and Internet data sources in the field of innovation activity; } \\
\text { search and selection of innovative projects, proposals for the production } \\
\text { of high-tech products for organizations and individuals interested } \\
\text { in financing them }\end{array}$ \\
\hline Personnel potential & $\begin{array}{l}\text { For innovation is crucial forms the basis for the formation of all other } \\
\text { necessary resources }\end{array}$ \\
\hline Financial support & $\begin{array}{l}\text { The development of innovation activity should integrate the finances } \\
\text { of the state, business and scientific organizations. The main priority is direct } \\
\text { financing by the state or granting privileges to the enterprises operating } \\
\text { in the scientific and technical field, restoration of the State Innovation Fund, } \\
\text { stimulation of foreign investments, development of the lending system } \\
\text { of innovative developments and their realization }\end{array}$ \\
\hline State regulation & $\begin{array}{l}\text { Creation of conditions and support of small farms and family farmers } \\
\text { associations (in particular, cooperatives) as a means of expanding } \\
\text { investment opportunities of such producers, promotion of scientific and } \\
\text { technological innovations in their environment; intensifying the activities of } \\
\text { scientific institutions in cooperation with agricultural enterprises and } \\
\text { improving the awareness of farmers in the field of innovation }\end{array}$ \\
\hline
\end{tabular}

Sources: [12]. 
Regarding the situation characteristic for agrarian business based on the analysis of such business, the following aspects are stated. Throughout the course of research of agricultural enterprise expectations in 2019, which covered perspectives on their business activity development, the State Statistics Service experts [16] conducted a survey among enterprises animal husbandry and crop producers. As a result of the research, out of 589 interviewed crop producers, $75 \%$ anticipate the growth in production volume, $41 \%$ hope for the price increase of the produced goods, $44 \%$ state that there will be no changes in prices, and $15 \%$ believe that prices may decrease. Forecasts of animal husbandry producers are somewhat less optimistic. Thus, out of 238 interviewed enterprises only $52 \%$ inform about the increase in production volume. Regarding the price change, the majority of believe that prices will remain the same $(76 \%)$. Overall, anticipations of enterprises, both animal husbandry and crop producers, have increased, in comparison to the results of a previous quarter.

Considering the results of other researchers on the creation of new forms of business entities in rural areas [23], answers the question regarding the types of necessary measures for its modern development, the majority of respondents mentioned easing taxation for small businesses and strengthening legal framework related to the discussed area (figure).

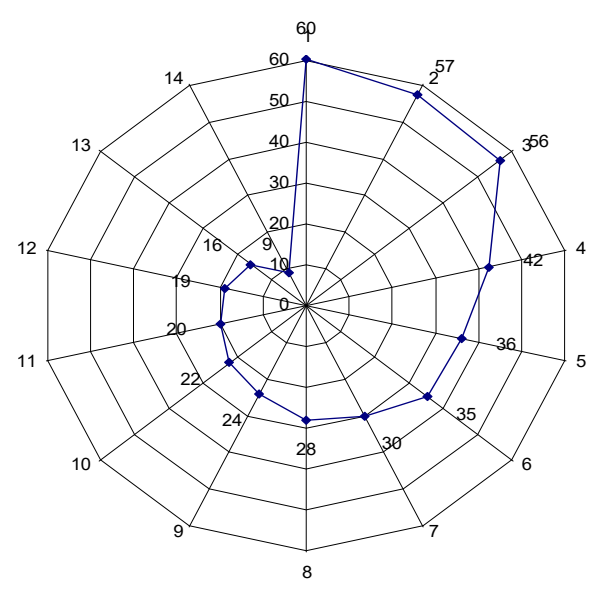

1. Improving the tax climate for small enterprises.

2. Developing financial support mechanisms.

3 . Simplifying registration procedure.

4. Informational support.

5. Developing regional infrastructure.

6. Simplifying registration of property rights and lease relations for SMEs.

7. Facilitating the improvement of the logistical base for small businesses.

8. Encouraging small businesses to participate in the innovation sphere.

9. Activating enterprise reform processes.

10. Establishing special economic zones.

11. Facilitating specialist training programs.

12. Creating a marketing risk insurance system.

13. Creating mutual lending mechanisms.

14. Other measures.

\section{Assessment of the motivation factors of small agrarian entrepreneurship}

Sources: indicate [23].

Analyzing the factors that prevent agrarian business development, respondents stressed high tax burden, low loans availability and other forms of external funding, insufficient development of information channels and networks, strong competition on the domestic and foreign markets, etc. The author argues that lack of adequate and forehanded information prevents entrepreneurs from cooperation with governmental agencies. Respondents' 
answers substantiate the claim about existing issues with the informational segment as they state that the utility of information sources aimed at supporting small businesses is low [23].

Concerning the Government's actions, support of farming is prioritized, as well as the development of the agricultural cooperatives. This decision has been carried out in the Concept of development of farms and agricultural cooperatives for 2018-2020 [24]. Moreover, the EU has ratified additional duty-free import quotas for a number of Ukrainian agricultural products (cereals, honey, processed tomatoes, grape juice) [22], which are supposed to facilitate development of the business as a result of systemic reform measures.

The support system for farmers was introduced in 2017 and became ineffective. Currently, support for the agricultural sector is provided mostly through a set of programs, aimed at increasing production efficiency and profitability of the producer. Meanwhile, due to lack of funds in the State Budget of Ukraine, this support is not able to compensate for the repealed tax regimes, which provided agricultural enterprises with the greatest advantages.

A. Vdovichenko argues in this particular case that "it is worth noting the processes that occur in the economy under tax incentives for agriculture and the absence of such incentives for the rest of the economy: the transfer of resources from a more efficient service sector and processing industry to a less efficient agricultural sector; keeping agriculture as basic industry in the production structure, whereas market demand may require the development of an industry or the service sector of the national economy; reorientation of enterprises of other profile to agriculture in order to maintain unprofitable agricultural productions for the ability to claim tax benefits; distortions within agriculture itself in favor of businesses with higher incomes from smaller areas, such as livestock enterprises " [25].

2020 budget has the foundation for the significant potential of business development. On 19 February the Cabinet of Ministers of Ukraine passed the act which defines the direction of the support of agrarians in 2020 under the 1201150 program "Financial help for agriculture producers". The state budget allocates UAH 4 bln for the realization of this program. Funds will be spent on the reduction of lending cost, reimbursement for the purchase of agricultural machinery assembled by Ukrainian producers, etc. The Cabinet is planning on channeling UAH 1 bln to the support of animal husbandry development and reprocessing of agricultural commodities, as well as to the partial reimbursement of the machinery costs and equipment produced by the domestic manufacturers. In terms of financial support of the agro-industrial complex, it is planned to allocate UAH 1.2 bln to reduce the cost of loans which, according to the Cabinet's calculations, allows cheapening lending costs by UAH $15.5 \mathrm{bln}$, in particular, UAH $7.2 \mathrm{bln}$ - shortterm loans, UAH 8.3 bln - mid-term and long-term loans, as it is stated in the message. UAH 185 bln were allocated for the financial support of farm 
development, UAH $400 \mathrm{mln}$ for the development of horticulture, viniculture, and hop-growing. Furthermore, UAH $215 \mathrm{mln}$ are planned to be spent on additional financial support through a co-payment mechanism in favor of insured persons [26].

Overall, innovation as a development factor exposes the necessity of a fundamental reconstruction founded on advances principles and developments [27, p. 24]. It is noted, "innovation development, aimed at the resolution of internal issues of a country for the provision of population prosperity by the means of fundamental reconstruction of the economy structure and deploying its inner potentials in a reflexive interaction with the external environment, ... not directly linked to GDP growth, and may occur even at negative growth rates" [27].

Therefore, innovation in a favorable regulatory environment, even in the absence of economic growth, can provide breakthrough solutions in terms of resource and energy savings, which is currently decisive in the global competition for agricultural producers.

Conclusion. Therefore, a new format of agrarian entrepreneurship in the context of systemic reforms receives an increasing impulses for action. Innovation development is extremely widespread in developed countries, so it is becoming the principal and determining vector. We consider that systemic reforms directly influence the condition and development of business. According to the statistical data, it has been revealed that medium and small agrarian enterprises, which rely on the middle-class initiative and are the form of self-employment for rural inhabitants, play the most significant role in the development of agrarian entrepreneurship.

At present, agricultural producers, who mainly take into account market factors, have some contradictions in relation to scientists, who are guided in their activities by the desire for new knowledge. Therefore, in our opinion, the combination of such different vector interests is possible only in the state representation, which will provide an opportunity to balance and regulate interests.

To intensify innovation in the agricultural sector of the economy is important to provide a high level of training of specialists and workers of the agro-industrial complex of Ukraine, combining science with production and rational use of knowledge base in improving the efficiency of agroindustrial production based on innovative entrepreneurship.

Innovation development currently presents itself as a unique way of action for agrarian business due to the fact that the range of activities, biological and climatic dependencies of doing business, need to use large amounts of fixed assets, the involvement of labor, need for branched infrastructure and logistics leave no choice for further strategy. Innovation development will facilitate efficient use of material, finance, and biological resources, allow to optimize production and management decisions, minimize and improve time expense, which allows agrarian entrepreneurship to expand markets and geography of sales and make profit. 
In addition, systemic reforms are in a permanent state, they are constantly characterized by breakthrough ideas due to the new technology, and this requires constant scientific support and adjustment, which is the direction of further research on this topic.

\section{REFERENCES}

1.Sabluk, P. T., \& Kropivko, M. M. (2018). Osoblivosti strategichnogo planuvannya rozvitku sil's'koï teritorial'noï gromadi. Ekonomika APK - The Economy of Agro-Industrial Complex, 3, 5-13 [in Ukrainian].

2.Malik, M. J. \& Shpykuljak, O. G. (2017). Rozvytok agrarnogo pidpryjemnyctva $\mathrm{v}$ umovah instytucional'nyh transformacij [Development of agrarian entrepreneurship in conditions of institutional transformations]. Ekonomika APK - The Economy of Agro-Industrial Complex, 2, 5-16 [in Ukrainian].

3.Babenko, A. H. \& Bondarevska, K. V. (2013). Rozvytok pidpryiemnytskoi diialnosti v ahrarnomu vyrobnytstvi Ukrainy (makroekonomichnyi aspekt) [Development of entrepreneurial activity in agrarian production of Ukraine (macroeconomic aspect)]. NAUKOVI PRATSI POLTAVSKOI DERZhAVNOI AHRARNOI AKADEMII. Is. 1 (6). (Vol. 2). Ekonomichni nauky - Economic Sciences, 8-13 [in Ukrainian].

4.Majovec', Je. J. (2006). Agrarne pidpryjemnyctvo v Ukrai'ni [Agrarian Entrepreneurship in Ukraine]. L'viv: Vydav. centr LNU im. Ivana Franka [in Ukrainian].

5.Dudnyk, O. S. (2015). Sut' ta umovy rozvytku pidpryjemnyctva v agrarnij sferi [The essence and conditions of entrepreneurship development in the agrarian sector]. Visnyk Cherkas'kogo universytetu - Bulletin of the Cherkasy Bohdan Khmelnytsky National University, 337, 41-45 [in Ukrainian].

6.Butenko, V. (2017). Innovative development of Ukraine as a basis for formation of bioeconomy. Agricultural and Resource Economicsю. International Scientific E-Journal [Online]. (Vol. 3), 1, 54-66, available at: www.are-journal.com [in English].

7.Sabluk, P. T. (2016). Innovacijna model' rozvytku agrarnogo sektoru ekonomiky Ukrai'ny ta rol' nauky v i'i' stanovlenni [Innovative model of the agrarian sector development of Ukraine's economy and the role of science in its formation]. Problemy innovacijno-investycijnogo rozvytku - Problems of innovation and investment development, 9, 34-42 [in Ukrainian].

8.Lunova, V. A., Bagmat P. D. (2019). Osoblivosti innovacijnogo rozvitku v agrarnomu sektori: zb.nauk. prac "Problemi i perspektivi rozvitku pidpriyemnictva", 137-147 [in Ukrainian].

9.Maznevб, G. E. (2016). Innovative aktivities as a factor improving the efficiency of agricultural production. Aktual'ni problemy innovatsiynoyi ekonomiky Actual problems of innovative economy, 236-47 [in Ukrainian].

10. Maznyev, G. Ye. (2017). Upravlinnya innovacijnim rozvitkom agrarnih pidpriyemstv. Aktualni problemi innovacijnoyi ekonomiki - Actual problems of innovative economy, 2, 32-41[in Ukrainian].

11. Moroz, S., Shramko, I. (2017). Using of information technologies in agrarian marketing. Visnyk Dnipropetrovs'kogo Derzhavnogo Agrarno-economichnogo Universytetu - News of Dnipropetrovsk State Agrarian and Economic University. 2, 117-122 [in Ukrainian]. 
12. Shebanin, V. S., \& Kormishkin Yu. A. (2019). Formi innovacijnoyi aktivizaciyi agrarnogo pidpriyemnictva $\mathrm{v}$ umovah cifrovoyi transformaciyi ekonomiki [Forms of innovative activity of agrarian entrepreneurship in the conditions of digital transformation of economy]. Ekonomika APK - The Economy of Agro-Industrial Complex, 10,18 [in Ukrainian].

13. Shebanina, O. V., \& Kormishkin, Yu. A. (2019). Suchasna paradigma innovacijnogo rozvitku agrarnogo pidpriyemnictva [Modern paradigm of innovative development of agrarian entrepreneurship]. Visnik agrarnoyi nauki Prichornomor'ya - Ukrainian Black Sea Region Agrarian Science, 3 (103),4-10 [in Ukrainian].

14. Yanchenko, Z. B. (2013). Innovatsï v silskomu gospodarstvi [Innovations in agriculture]. Polissya, 692 [in Ukrainian].

15. Bilins'ka, V. (2015). Suchasni innovacijni tehnologii' v sil's'komu gospodarstvi: osnovna harakterystyka ta perspektyvy vprovadzhennja [Modern innovative technologies in agriculture: the main characteristic and the prospects of implementation]. Visnyk Kyi'vs'kogo nacional'nogo universytetu imeni Tarasa Shevchenka. Ekonomika - Bulletin of Taras Shevchenko National University of Kyiv. Economics 7, 74-80 [in Ukrainian].

16. Sajt Derzhavnoi' sluzhby statystyky Ukrai'ny [The site of the State Statistics Service of Ukraine]. Retrieved from www.ukrstat.gov.ua [in Ukrainian].

17. Sajt Minagropolityky [The site of the Ministry of Agrarian Policy]. Retrieved from http://minagro.gov.ua/node/25577 [in Ukrainian].

18. Ministry of Education and Science of Ukraine Ukrainian Institute of Scientific and Technical Expertise and Information Analytical information State of development of science and technology, results of scientific and technical activity for 2019. Retrieved from https://mon.gov.ua/storage/app/media/nauka/ informatsiyno-analitychni/2020/06/ realizatsiya-prioritetiv-nauki-i-tekhniki-u2019-r150620.pdf [in Ukrainian].

19. The Legatum Institute [The Legatum Institute]. Retrieved from https://www.li.com [in Ukrainian].

20. Analytical Report on Innovation and Technology Transfer Activity in Ukraine in 2019. Retrieved from https://mon.gov.ua/storage/app/media/innovatsiitransfer-tehnologiy/2020/08/za-2019-1-1.pdf.

21. Agrarian Innovation 2018 | ProAgro Retrieved from http://www.proagro.com.ua/ events/innovation2018/ [in Ukrainian].

22. ISD. Ukrai'na u 2017: makroekonomichnyj ogljad [ISD Ukraine in 2017: macroeconomic review]. Retrieved from http://www.ier.com.ua/ua/institute/ news?pid=5849 [in Ukrainian].

23. Zaburanna, L. V. (2012). Doslidzhennja motyvacii' pidpryjemciv u sferi sil's'kogo agrarnogo turyzmu [Investigation of the motivation of entrepreneurs in the field of rural agrarian tourism]. Ekonomika. Upravlinnja. Innovacii' Economy. Management. Innovations, 2 (8). Retrieved from http://nbuv.gov.ua/ UJRN/eui_2012_2_16. [in Ukrainian].

24. Koncepcija rozvytku fermers'kyh gospodarstv ta sil's'kogospodars'koi' kooperacii' na 2018-2020 roky vid 13.09.2017 [Concept of development of farms and agricultural cooperatives for 2018-2020 from 13.09.2017 №. 664-p.] Retrieved from http://zakon3.rada.gov.ua/laws/show/664-2017-\%D1 \%80 [in Ukrainian]. 
25. Vdovychenko, A. Jedynyj podatok chetvertoi' grupy v konteksti reformuvannja opodatkuvannja sil's'kogo gospodarstva v Ukrai'ni [The only tax in the fourth group in the context of reforming the taxation of agriculture in Ukraine]. ngoipr.org.ua. Retrieved from http://ngoipr.org.ua/blog/yedynyj-podatok-chetvertoyigrupy-v-konteksti-reformuvannya-opodatkuvannya-silskogo-gospodarstva-vukrayini/ [in Ukrainian].

26. Uriad rozpodilyv 4 mlrd hrn derzhpidtrymky APK na 2020 rik [The government has allocated 4 billion UAH of state support for agriculture in 2020]. Retrieved from https://agropolit.com/news/15421-uryad-rozpodiliv-4-mlrd-grnderjpidtrimki-apk-na-2020-rik?fbclid=IwAR3_MCakPMeT3Rx2gRhsZtM20gHY mzd3t1i70EkGXDsC8-1mibbC6JfrWsM [in Ukrainian].

27. Gejcja, V. M \& Grycenko, A. A. (2016). Rekonstruktyvnyj ekonomichnyj rozvytok: osnovni naprjamy, efektyvnist' i social'na spravedlyvist': monografichnyj zbirnyk [Reconstructive economic development: main directions, efficiency and social justice: monograph collection]. DU "In-t ekon. ta prognozuv. NAN Ukrai'ny". Kyiv, 240 [in Ukrainian].

The article submitted to editor's office on 18.02.2021.

Кулік А. Інноваційний розвиток аграрного підприємництва.

Постановка проблеми. Узагальнення стану та перспектив становлення 6 межах наукової дискусї̈ питання інноваційного розвитку аграрного підприємництва $\epsilon$ важливим завданням, актуальність якого визначається тим, щуо, прагнучи дотримуватися основних принцииів агроінноваційного розвитку, вітчизняна практика має враховувати особливості й можливості аграрного сектора, його стан та менталітет.

Аналіз останніх досліджень і публікацій показав, щзо питання інноваційного розвитку аграрного підприємництва потребують подальшого вивчення та обговорення в науковому світі.

Метою статті є дослідження впливу нових економічних реалій, обумовлених системними реформами в економіці на інновачійний розвиток аграрного підприємництвв Украӥни для формування перспективних напрямів його розвитку.

Матеріали та методи. Методичним інструментарієм проведеного дослідження стали методи економічної теорї; порівнянь та статистичного аналізу; формалізаиії. Періодом дослідження обрано 2010-2019 рр.

Результати дослідження. Сучасний стан аграрної галузі обумовлюється глобальним впливом технологічної модернізації, яка не завжди є доцільною $і$ не відповідає дійсним потребам та можслиостям сільськогосподарських виробників.

Систематизація наукових джерел та підходів до вирішення проблем інноваційного розвитку аграрного підприємництва засвідчила значний вплив нових економічних реалій, обумовлених системними реформами в економіці та сільському господарстві на інноваційний розвиток аграрного підприсмництва України. За статистичними даними установлено, як саме реагує аграрне підприємництво на проведені реформи.

Висновки. Встановлено, що загалом досягнення аграрного підприємництва досить суттєві, але факторами впливу є насамперед значний земельний банк, дешева робоча сила, пільги в оподаткуванні, державна підтримка у виробництві та експорті окремих товарних позищій галузі. Реформи несуттєво впливають на підприємнищьку діяльність, вони дуже повільно, іноді з протилежним ефектом, стимулюють розвиток сільського підприсмнищтва. У той час як у світі агропрочеси дедалі більш автоматизуються, в Украӥні досі широко застосовуються застарілі методи ведення господарства. Саме тому необхідно розробити стратегію інноваційного розвитку галузі та, спираючись на історичний досвід і новітні досягнення, розробити етапи ї̈ реалізащії.

Ключові слова: аграрний сектор, підприємництво, системні реформи, інноваційний розвиток, форми господарювання, стратегія. 